| Keterpurukan Sektor Pertanian

\title{
KETERPURUKAN SEKTOR PERTANIAN SEBAGAI POTRET KEGAGALAN INDUSTRIALISASI DI INDONESIA
}

\author{
Grendi Hendrastomo ${ }^{1}$
}

\begin{abstract}
Shifting agricultural era to the era of industrialization left many problems, especially in the agricultural sector. Populist policies have on one hand brought the country many industrial investments that force economic growth, but on the other hand reduced the partisanship of country in agricultural sector. Agriculture as the basis for mass production of most Indonesian society has became casualties as part of the green revolution that is full of developing countries's propaganda which brings benefit and lead to dependency on developing countries. The downturn actors of agricultural field increased in line with growth of food-estate program to attract foreign investors to explore the agro sector. This article discusses on a critical review of agriculture in Indonesia's slump that began with the green revolution with their panca usaha tani, starting from the decline of the agricultural sector, static industrial situation until the solutions that might be applied to enhance the economic growth and social dynamics of Indonesia.
\end{abstract}

Keywords: Industrialisation, Marginalization of Agriculture, Green Revolution

1 Pengajar di Program Studi Pendidikan Sosiologi, Fakultas Ilmu Sosial, UNY. Email:
ghendrastomo@yahoo.com

DIMENSIA, Volume 5, No. 1, Maret 2011 | 71 


\section{A. Pendahuluan}

Berbicara tentang Indonesia tentu tidak terlepas dari laut dan daratannya. Sumber daya alam kita yang luar biasa besarnya menjadi modal kita untuk memompa pertumbuhan ekonomi dan menghasilkan devisa yang cukup untuk kesejahteraan rakyatnya. Kekayaan laut dengan beraneka ragam jenis ikan dan kuantitas ikan yang besar menjadi ladang subur bagi nelayan. Tanah kita yang subur, merupakan modal berharga negara ini untuk menjadi negara agraris. Sedikit gambaran di atas merupakan gambaran kebanggaan kita akan sumber daya yang luar biasa yang terkandung di dalam bumi kita. Seharusnya bangsa kita bisa maju dan menjadi ujung tombak perekonomian dunia dengan melihat limpahan sumber daya alam yang luar biasa. Apabila kita mau untuk mengolah, memanfaatkan dan menggunakannya dengan bijak, kemungkinan besar hal tersebut bukan hanya utopia belaka.

Ironisnya, apa yang terpampang di mata kita memang benar-benar merupakan sebuah utopia. Ternyata kita justru menjadi budak di negeri kita sendiri. Negeri yang merdeka hanyalah sekedar kata-kata karena ternyata sampai saat ini pun kita masih dijajah. Sumber daya minyak kita dikuasai oleh perusahaan asing, yang justru mendapatkan keuntungan lebih besar dari apa yang mereka berikan pada negara. Nelayan kita dijajah oleh kapal-kapal berbendera asing yang dengan peralatan modernnya mampu mengeruk ikan berkali-kali lipat lebih besar dari nelayan tradisional kita. Tanah kita yang subur ternyata tidak lagi menjadi kebanggaan kita, ketika di atas tanah-tanah subur tersebut dibangun berbagai macam infrastruktur yang lagi-lagi merupakan salah satu bentuk penjajahan gaya baru (neokolonialisme) yang mengkooptasi pertanian kita dan digantikan dengan industri-industri dengan mesin-mesin modern dan kepentingan kapitalistik belaka. Indonesia sekedar menjadi pasar, sasaran eksploitasi alam dan sasaran eksploitasi tenaga kerja murah bagi kemajuan negaranegara kapitalis maju (Oktavianus, 2008)

Pertumbuhan pesat sektor industri sedikit banyak telah mengubah paradigma masyarakat dan negara dari agraris ke sektor industri dan jasa. Tawaran industri yang mempromosikan modernitas, hidup sejahtera, jam kerja yang teratur dengan penghasilan tetap, telah memunculkan perubahan radikal dalam tatanan sosial ekonomi kita. Sektor pertanian yang notabene menjadi basis perekonomian kita, sedikit demi sedikit diganti dengan industrialisasi. Ada usaha untuk mengubah mata pencaharian pokok masyarakat dari sektor pertanian ke sektor industri. Dengan asumsi bahwa sektor pertanian akan bisa berjalan beriringan dengan sektor industri. Kenyataannya, justru sektor pertanian mengalami kemunduran, sektor industri pun jalan ditempat, dan apa yang diharapkan bahwa kesejahteraan 
masyarakat akan meningkat yang terjadi justru sebaliknya. Kemudian, siapa yang diuntungkan dengan keadaan ini? Ada kecenderungan tumbuhnya sektor industri justru diikuti dengan kenaikan pola konsumsi masyarakat dimana konsumtivisme dipaksakan menjadi budaya dominan sehingga pengangguran semakin banyak, munculnya masalah sosial dan kantong kemiskinan di perkotaan hingga hancurnya sektor pertanian.

Industrialisasi yang kita banggakan hanyalah industrialisasi semu, yang mana industri yang ada di Indonesia hanyalah pengalihan produksi dari negara maju. Kita bangga banyak investor masuk dan membuka usaha di negara kita, tetapi semua bahan produksinya ternyata bukan berasal dari negara kita. Kita hanya sekedar menyediakan tempat dan sumber daya manusia yang murah, tanpa pernah bisa mengembangkan diri, menyerap ilmu dan teknologi maju hingga mengembangkan industri yang berbasis pada lokalitas. Industrialisasi yang setengahsetengah justru menghadirkan malapetaka lain di sektor pertanian, banyak lahan dialih fungsikan sebagai pabrik-pabrik, pemuda desa diiming-imingi gaji tetap dan modernitas, hingga akhirnya sektor pertanian yang selama ini menjadi fondasi perekonomian kita mengalami kemunduran. Pertanian kita semakin tertinggal dari Thailand, petani kita semakin miskin dan akhirnya sektor pertanian tidak lagi menjadi ladang emas bagi masyarakat. Kondisi ini diperparah dengan kebijakan dan rencana pembangunan yang berat sebelah. Alih-alih menjadikan pertanian sebagai fondasi pembangunan, justru dimasukkan industri-industri modern dan berteknologi tinggi yang padat modal dan memerlukan biaya investasi yang besar. Lompatan luar biasa dalam tatanan kehidupan sosial ekonomi inilah yang dibanggakan sebagai keberhasilan pembangunan.

Hingga saat ini pembangunan di Indonesia banyak bertumpu pada sektor industri dan jasa, yang dianggap memiliki nilai tambah untuk memacu pertumbuhan ekonomi. Pembangunan yang berbasis pada industri murni kemudian bertolak pada banyak agenda yang dibangun oleh negara-negara barat, dimana kemajuan dan perubahan masyarakat akan lebih cepat ketika kehidupan sosial ekonomi kita berbasis pada sektor industri. Selama orde baru hingga saat ini, terlihat ada pergeseran struktur ekonomi kita yang pada mulanya berbasis pada sektor pertanian, lambat laun berganti dengan industri dan jasa. Pergeseran tersebut ditandai dengan semakin merosotnya peranan sektor pertanian dan meningkatnya peranan sektor industri dan jasa.

Perubahan dinamika kehidupan ini lambat laun juga diikuti dengan perubahan sosial masyarakatnya. Di era tahun 80-an sangat mudah kita temukan banyak 
sentra-sentra produksi pertanian yang masyarakatnya hidup sejahtera. Dimana-mana sektor pertanian tumbuh dan berkembang seiring kebutuhan dan politik pangan yang kondusif. Selama tahun-tahun itulah kita dibawa pada swasembada beras yang bisa dilihat dari dua sisi. Pertama, bisa dilihat sebagai prestasi emas yang patut dibanggakan. Kedua, menjadi titik tolak terpuruknya sektor pertanian, yang kemudian nantinya akan sedikit banyak dibahas dalam analisis tulisan ini untuk melihat keruntuhan sektor pertanian yang kemudian digantikan dengan industri.

\section{B. Menuju Masyarakat Industri}

Perkembangan masyarakat Indonesia merupakan perubahan yang kompleks dalam tatanan kehidupan sosial ekonomi. Ada lompatan pola perkembangan yang mungkin tidak ditemukan di negara-negara maju dan menjadi karakteristik dari negara-negara dunia ketiga. Perkembangan masyarakat menurut Malinowski (Laeyendecker, 1983) mengikuti pola perkembangan yang umumnya terjadi di masyarakat dunia yaitu hunting $\mathcal{E}$ gathering, hortikultura \& pastoral, agricultural, industrial dan post industrial. Lompatan besar yang disebut sebagai revolusi kebudayaan justru berada pada fase agricultural dimana fase ini justru menjadi landasan bagi perkembangan masyarakat ke arah Industri. Pada fase ini terjadi perubahan sosial politik, ekonomi kapitalistik, perkembangan iptek dan modernisasi. Pada fase ini, walaupun masih berbasis pada pertanian, tetapi mulai diperkenalkan teknologi yang dipergunakan sebagai rekayasa alam, sehingga pertanian tradisional yang umumnya bergantung pada alam, dibantu dengan munculnya teknologi. Fase inilah yang akan mengantarkan perkembangan masyarakat ke arah industri.

Fase perkembangan masyarakat yang berkaca pada negara maju ketika kita tempatkan dalam konteks Indonesia, memunculkan sesuatu yang menarik. Ada sedikit lompatan dimana fondasi kita pada fase agricultural belum kokoh benar tetapi langsung diperkenalkan dengan industri. Percepatan perkembangan inilah yang dikemudian hari justru memunculkan banyak persoalan dalam masyarakat. Perkembangan industri yang ada sekarang tidak pernah lepas dari campur tangan negara maju. Ada kecenderungan banyak negara-negara dunia ketiga yang ingin mengikuti jejak negara maju yang industrinya mampu menopang kesejahteraan rakyatnya.

Belajar dari pengalaman pembangunan di negara-negara maju, muncul keyakinan di banyak negara sedang berkembang bahwa industri dipandang sebagai jalan pintas untuk meningkatkan kesejahteraan masyarakat dan mengejar ketinggalan dari negara maju. Di satu sisi, industri dapat mengikis keterbelakangan, kemiskinan dan mempercepat proses modernisasi, sehingga industri ditempatkan sebagai variabel tunggal dalam strategi 
pembangunan (Effendy, 1995). Inilah yang kemudian memacu banyak negara dunia ketiga untuk mengadopsi model industrialisasi di negara maju untuk diterapkan dinegara dunia ketiga tak terkecuali di Indonesia.

Industrialisasi adalah proses perubahan ekonomi dari ekonomi berbasis pertanian ke ekonomi berbasis industri. Tetapi, ada juga beberapa ilmuwan yang menggaris bawahi bahwa industrialisasi tidak semata-mata berkaca pada sisi ekonomi saja, melainakan proses perubahan sosial dan ekonomi, dimana masyarakat ditransformasikan dari tahap atau keadaan pra industri ketika akumulasi modal perkapita rendah ke tahap industrialisasi (Daeng, 2009). Dengan demikian, industrialisasi bukan hanya transformasi dalam bidang ekonomi tetapi juga transformasi sosial.

Budaya memegang peran penting dalam keberhasilan sektor industri. Perkembangan industri di banyak negara maju berhasil dilakukan dikarenakan ada perubahan budaya masyarakat yang mampu menopang terbentuknya budaya industri. Dalam hal ini, budaya industri merupakan pengejawantahan dari menjadikan barang, baik barang jadi maupun barang mentah menjadi sesuatu yang mempunyai nilai tambah yang ketika diproduksi justru nilai jualnya akan meningkat. Sebagai contoh, kerang mutiara ketika dijual langsung harganya akan cenderung murah apabila dibandingkan dengan mutiara yang diolah, lain halnya apaila dijadikan perhiasan yang akan meningkatkan nilai jual produksi. Dari keadaan tersebut dapat kita lihat bahwa perubahan budaya memang kemudian bertumpu pada etos, prinsip yang dibangun dan yang sudah ada di masyarakat.

Merujuk pada Weber (2006) dalam etika protestan dan spirit kapitalisme, industri di Eropa berkembang pesat karena budaya dan etos kerja orang Eropa yang menggangap bahwa kapitalisme bukanlah penindasan pada yang orang lain. Kapitalisme tidak dipandang sebagai mencari keuntungan sebesar-besarnya, kapitalisme merupakan sebuah budaya, sistem ekonomi yang dikembangkan yang menjadi ruh dari industrialisasi yang berkembang di Eropa pada waktu itu. Semangat kapitalisme adalah semangat penyelamatan, bagaimana menyelamatkan manusia lain dari memupuk keuntungan materi dan membangun basis produksi besar untuk menyelamatkan dan memakmurkan orang lain. Kondisi inilah yang menjadi landasan berkembangnya industrialisasi $\mathrm{di}$ Eropa. Artinya semangat, etos orang bukan lagi menjual sesuatu tetapi bagaimana mendayagunakan bahan mentah untuk diolah, dikembangkan dan disebarluaskan demi kepentingan bersama. Industrialisasi yang dibangun dari bawah inilah yang kemudian memunculkan modernisasi, yang kemudian akan berefek pada 
\begin{tabular}{llr} 
pertumbuhan & ekonomi dan \\
pendapatan, & \multicolumn{2}{r}{ kesejahteraan } \\
masyarakat & yang & semakin \\
meningkat. & & \\
\multicolumn{1}{c}{ Konsep } & Weber & tentang
\end{tabular}

Konsep Weber tentang penjelasan perkembangan budaya industri di Eropa tersebut di atas yang tampaknya mampu menjawab mengapa industrialisasi di Indonesia tidak berjalan layaknya di negara maju. Etos dan spirit industri di masyarakat kita belum tampak, ada kecenderungan bangsa ini beretos pedagang dimana karakteristiknya adalah menjual sesuatu dengan cepat dan mendapatkan keuntungan yang besar dari barang tersebut. Inilah yang kemudian menjadi alasan logis mengapa sumberdaya alam kita yang melimpah tidak mampu mensejahterakan rakyatnya, sebaliknya justru menjadi beban, karena kebijakan pemerintah bukan berkaca pada industrialisasi tetapi lebih pada etos dagang; mengapa harus susah-susah mengolah ketika tanpa diolahpun bisa menghasilkan.

Cara pandang yang sama juga berlaku ketika melihat industrialisasi di Indonesia. Industrialisasi di Indonesia selama ini tidak berlandaskan pada sektor pertanian yang notabene secara kultur dan budaya merupakan sektor yang paling mungkin dikembangkan dan menjadi landasan bagi industri lainnya. Sehingga akibat industrialisasi yang dipaksakan justru masyarakatnyalah yang tidak siap dalam menyongsong industrialisasi. Perkembangan masyarakat mengalami percepatan tanpa mampu diikuti oleh masyarakatnya sendiri. Akibat industrialisasi yang berbasis pada teknologi maju dan modern, justru pola konsumsi yang berubah dan industri menjadikan masyarakat sebagai bagian dari industri "seutuhnya", dalam artian selain menjadi pelaku industri juga menjadi konsumen produk-produk industri.

Merujuk pada negara Eropa, perkembangan masyarakat yang alamiah membentuk masyarakat industri untuk kemudian memunculkan modernisasi. Berkebalikan dengan di Indonesia, karena perkembangan masyarakat dipengaruhi oleh kolonialisasi dan imperalisme, maka perkembangan masyarakatnya pun tidak mengikuti pola modernisasi yang alamiah. Masyarakat modern dulu, baru menapak pada industrialisasi, yang mengakibatkan proses industrialisasi tidak pernah bisa tercapai karena masyarakatnya sudah modern dan menjadi penikmat dan peniru modernisasi yang sudah dulu ada di negara maju. Di satu sisi, industrialisasi gagal dilaksanakan, disisi lain sektor pertanian yang seharusnya dikembangkan justru semakin terpinggirkan.

C. Keterpurukan Sektor Pertanian

Di banyak negara, sektor pertanian yang berhasil merupakan prasyarat bagi pembangunan sektor industri dan jasa. Sehingga pada awalnya rencana pembangunan yang ideal menitik beratkan pada pembangunan sektor pertanian. Pada tahap pertama, pembangunan dititikberatkan pada pembangunan sektor pertanian dan industri penghasil sarana produksi 
Keterpurukan Sektor Pertanian

pertanian. Tahap kedua, pembangunan dititikberatkan pada industri pengolahan penunjang sektor pertanian (agroindustry) yang selanjutnya secara bertahap dialihkan pada pembangunan industri mesin dan logam (Suhendra, 2004). Struktur industri yang demikian akan membentuk struktur perekonomian yang tangguh dan mampu menghadapi tantangan global.

Konsep ideal industrialisasi tersebut tenyata sulit untuk diwujudkan di Indonesia, yang terjadi justru perubahan strategi pembangunan dari industri berbasis pertanian "melompat" ke industrialisasi berspektrum luas (broad base industry strategy) dan industri canggih (hi-tech industry) yang banyak menyandarkan diri pada bahan baku impor. Industri canggih semacam ini sangat rentan terhadap gejolak kurs rupiah, memboroskan cadangan devisa dan memperbesar ketergantungan Indonesia pada negara lain (Noertjahyo, 2005).

Kekhawatiran ketergantungan pada negara lain ini terbukti ketika seluruh industri termaju di Indonesia saat ini tidak berdiri di atas kebutuhan ekonomi dalam negeri, melainkan atas permintaan dan kebutuhan ekspansi modal asing (Oktavianus, 2008). Bila dibandingkan, sistem yang berjalan sekarang hanyalah kelanjutan dari sistem ekonomi kolonial, yang sempat terinterupsi sejenak di masa revolusi kemerdekaan dan separuh masa pemerintahan nasionalis
Sukarno. Dalam perspektif Andre Gunder Frank, (Budiman, 2000) ketergantungan yang dialami negara-negara dunia ketiga merupakan akibat keterbelanganan yang banyak mendominasi negaranegara tersebut. Untuk memompa dan mempercepat pembangunan maka diperlukan bantuan modal asing yang banyak disokong oleh negara-negara maju, sehingga tidak heran apabila banyak kebijakan yang ada di negara dunia ketiga merupakan perpanjangan tangan dari negara maju. Industrialisasi yang terjadi kemudian diarahkan untuk kepentingan negara-negara maju, dan efek ketergantungan ini semakin tampak ketika konsepkonsep liberalisasi mulai diperkenalkan di negara-negara dunia ketiga.

Perubahan strategi

pembangunan itu secara pelan tapi pasti terus meminggirkan sektor pertanian dan petani. Bahkan, boleh dikatakan nyaris melupakannya. Nasib para petani yang selama ini akrab dengan kesengsaraan tidak jua beranjak dari lembah kemiskinan. Padahal, merekalah ujung tombak penyedia bahan makanan. Penetrasi padat modal dalam industri teknologi dan manufaktur, menjadikan sektor pertanian sebagai sasaran ekploitasi kota terhadap desa. Saat industri manufaktur tumbuh pesat, tenaga produktif pertanian sama sekali tidak berkembang. Industri hanya menyentuh sektor pertanian sebagai pasar, sehingga proyek-proyek pedesaan pun dilakukan semata- 
mata untuk memuluskan tujuan tersebut. Apabila dilihat sekilas, pembangunan infrastruktur jalan, bendungan, pengenalan terhadap bibit dan pupuk jenis baru, tampaknya menguntungkan petani. Namun, karena tujuannya bukan untuk memajukan pertanian maka dampak yang dihasilkan pun justru merugikan petani dalam jangka panjang.

Industri yang dibangun
dengan ketergantungan pada
negara maju, mulai menerima kehancuran saat diintegrasikan ke dalam ekonomi global. Banyak tenaga produktif yang tersia-siakan atau bahkan sengaja dipinggirkan. Pabrik-pabrik di tutup, pengangguran meningkat, lahan pertanian produktif dirampas untuk industri yang sama sekali tidak menopang sektor pertanian, sementara sektor jasa terutama pemasaran merebak melampaui sektor industri. Ironisnya, merebaknya industri pemasaran bukan disebabkan oleh meningkatnya produksi dalam negeri, melainkan dampak dari dibukanya keran impor dalam perdagangan bebas. Liberalisasi perdagangan internasional akan memaksa para petani di negara yang sedang berkembang untuk bersaing dengan petani dari negara industri yang memiliki sistem pertanian yang lebih efisien.

Ketidakberpihakan industryalisasi pada sektor pertanian diperparah dengan dilakukannya kebijakan alih fungsi lahan untuk pembangunan pabrik-pabrik demi percepatan industri manufaktur. Berbagai macam proyek padat karya dilakukan untuk membangun infrastruktur demi untuk meningkatkan pertumbuhan industri. Proyek pembangunan infrastruktur tersebut tentu saja memerlukan lahan, yang lagi-lagi kemudian terbukti sebagian besar tanah yang digunakan untuk pembangunan adalah tanah yang semula dikuasai/dimiliki petani. Konversi lahan pertanian yang diikuti berdirinya banyak pabrik baru dan real estate yang menjamur dimana-mana, memunculkan masalah baru mengenai sumber daya air. Dimana-mana air menjadi rebutan, sungai tidak mampu menyediakan lagi kebutuhan pengairan bagi pertanian pada musim kemarau.

$$
\text { Masalah-masalah yang }
$$

muncul merupakan akibat dari semakin sempitnya lahan pertanian. Lebih menyedihkan lagi bahwa tanah yang dialihfungsikan umumnya dilokasi strategis, subur dan sangat produktif. Seharusnya petani yang memiliki tanah yang dialih fungsikan mendapatkan ganti rugi yang sesuai, tetapi kenyataannya justru dengan dalih pembangunan dan pertumbuhan industri, ganti rugi yang didapatkan justru jauh dibawah harga pasar. Hal ini bukti bahwa selama ini petani dipinggirkan dan tidak pernah mendapat perhatian dari pemerintah.

\section{Revolusi Hijau dan Industri Pertanian}

Sebenarnya sektor pertanian sudah pernah menikmati industrialisasi. Industrialisasi pertanian dimulai pada tahun 70-an 
dengan bergulirnya revolusi hijau. Pada waktu itu, revolusi hijau dianggap sebagai "juru selamat" bagi sektor pertanian, khususnya di negara berkembang. Oleh karena itu, tanpa revolusi hijau sulit dibayangkan bagaimana produksi pertanian akan mampu memberi makan bagi penduduk yang jumlahnya semakin meningkat.

Implementasi revolusi hijau yang merupakan salah satu cara mengindustrialisasi sektor pertanian di Indonesia adalah dengan program Panca Usaha Tani (pengunaan bibit unggul, pengolahan tanah, pemupukan, pengendalian hama, pengairan atau irigasi). Menurut Loekman Sutrisno (Noertjahyo, 2005), pelaksanaan revolusi hijau telah berhasil mengubah sikap petani, dari sikap anti teknologi ke sikap yang mau memanfaatkan teknologi pertanian modern, misalnya pupuk kimia, bibit padi unggul. Perubahan sikap petani tersebut sangat berpengaruh terhadap kenaikan produksi pangan sehingga Indonesia mencapai swasembada pangan. Tetapi revolusi hijau juga menimbulkan berbagai masalah bagi petani. Ketergantungan pada bibit unggul yang seragam dan meninggalkan bibit lokal yang dimiliki, subsektor tanaman pangan rentan terhadap berbagai hama, petani menjadi bodoh dengan melupakan banyak pengetahuan lokal dan menggantungkan diri pada paketpaket teknologi pertanian produk industri.
Kritik tajam hingga gerakan anti revolusi hijau kemudian bermunculan. Ongkos yang harus dibayar oleh program revolusi hijau ini adalah hilangnya institusi lokal, musnahnya keanekaragaman sumber daya hayati, menurunnya kualitas tanah, serta menurunnya kualitas lingkungan secara keseluruhan. Bahkan, meskipun revolusi hijau telah berhasil meningkatkan produktivitas dan produksi pertanian secara menakjubkan, akan tetapi gagal dalam meningkatkan kesejahteraan petani dan kemandirian pertanian. Inilah ongkos terbesar yang harus dibayar karena pertanian di Indonesia menjadi sangat bergantung pada industri raksasa pertanian dunia mulai dari pengadaan benih, pupuk, pestisida, hingga mesin-mesin pertanian. Apalagi, hampir semua proyekproyek besar pertanian (seperti pembangunan irigasi, pembelian alat-alat pertanian, dll) harus dibayar dengan utang.

Selintas revolusi hijau memang memajukan pertanian. Namun, jika ditelisik lebih jauh justru membuat petani semakin terdesak pada marginalitas, sehingga diperbudak oleh berbagai rekayasa teknologi negara-negara maju yang mahal harganya. Ekses negatif revolusi hijau dapat dirasakan hingga saat ini. Karena hilangnya teknologi lokal, menyebabkan petani sangat tergantung pada produk-produk pertanian buatan pabrik. Petani selalu menggunakan pupuk, 
pestisida untuk memberantas hama dan bibit tanaman yang digadanggadang unggul tetapi memerlukan pupuk dalam jumlah banyak. Bencana bagi petani datang ketika pupuk mulai susah ditemui, entah karena tangan jahat atau akal-akalan perusahaan penyedia pupuk untuk menaikkan harga. Petani yang sudah terlanjur tergantung akhirnya menjadi semakin terpuruk.

Beban akibat revolusi hijau itu semakin melengkapi kendala yang melekat pada para petani. Mulai kepemilikan tanah yang semakin sempit, akibat kekurangan modal dan tanggungan resiko gagal panen, sulitnya memperoleh kredit, terbatasnya sarana dan prasarana hingga terjadinya degradasi sumber daya alam.

\section{E. Membangun Ulang Industri Pertanian}

Tak bisa dipungkiri sektor pertanian sudah menjadi urat nadi bangsa ini. Ketika industrialisasi jalan ditempat, tidak salah kiranya untuk mencoba mereformulasikan industrialisasi di negara ini. Sebagai titik tolak perlu kiranya untuk melihat anugerah yang dimiliki bangsa ini dengan tanahnya yang subur untuk memulai industrialisasi dari sektor pertanian. Sebuah langkah yang tidak mudah, karena tidak hanya mereformulasikan industrialisasi dari segi ekonomi saja tetapi juga dari segi budaya dan sosial.

Merubah etos masyarakat dari etos pedagang menjadi seorang industriawan bukanlah semudah membalikkan tangan. Himpitan ekonomi dan kebutuhan sehari-hari yang mendesak akan mendorong masyarakat untuk secepat mungkin memperoleh keuntungan dari apapun yang dimiliki dan bisa diperjual belikan. Memunculkan etos industri memerlukan waktu yang relative lama, mulai dari mengeksploitasi sumber daya alam yang dimiliki dalam bentuk bahan mentah, mengolahnya menjadi setengah jadi hingga mengemasnya dan menciptakan produk-produk yang siap pakai.

Akselerasi sektor pertanian kiranya menjadi sangat penting untuk mengoptimalkan dan menjadikan sektor ini sebagai landasan bagi industrialisasi. Merujuk pada Simatupang (Suhendra, 2004:57-58), akselerasi sektor pertanian di Indonesia menjadi sesuatu hal yang krusial karena:

a. Sektor pertanian masih tetap sebagai penyerap tenaga kerja, sehingga akselerasi pembangunan sektor pertanian akan membantu mengatasi masalah penggangguran.

b. Sektor pertanian merupakan penopang utama perekonomian desa dimana sebagian besar penduduk berada. Oleh karena itu, akselerasi pembangunan pertanian paling tepat untuk mendorong perekonomian desa dalam rangka meningkatkan pendapatan sebagian besar penduduk Indonesia dan sekaligus pengentasan kemiskinan.

c. Sektor pertanian sebagai penghasil makanan pokok 
penduduk, sehingga dengan akselerasi pembangunan pertanian maka penyediaan pangan dapat terjamin. Langkah ini penting untuk mengurangi ketergantungan pangan pada pasar dunia.

d. Harga produk pertanian memiliki bobot yang besar dalam indeks harga konsumen sehingga dinamikanya amat berpengaruh terhadap laju inflasi. Oleh karena itu, akselerasi pembangunan pertanian akan membantu menjaga stabilitas perekonomian Indonesia.

e. Akselerasi pembangunan pertanian sangatlah penting dalam rangka mendorong ekspor dan mengurangi impor produk pertanian, sehingga dalam hal ini dapat membantu menjaga keseimbangan neraca pembayaran.

f. Akselerasi pembangunan pertanian mampu meningkatkan kinerja sektor industri. Hal ini karena terdapat keterkaitan yang erat antara sektor pertanian dengan sektor industri yang meliputi keterkaitan produk, konsumsi dan investasi.

Tentunya akselerasi tersebut juga harus didukung dengan berbagai kebijakan yang pro pertanian, mempermudah akses bibit murah, pupuk yang tak terbatas, perbaikan sarana irigasi dan penggunaan teknologi sederhana dan tepat guna merupakan poin mutlak yang harus diperbaiki dari awal. Pemberdayaan berbasis komunitas perlu digerakkan untuk memutus mata rantai ketergantungan pada produkproduk pendukung pertanian yang berasal dari negara lain. Merujuk pada tren dunia akan makanan yang sehat, maka perlu digalakkan pertanian organic dimana penanaman tanpa menggunakan bahan-bahan kimia, artinya disatu sisi, memutus mata rantai ketergantungan pada pupuk kimia, disisi lain harga panen akan lebih tinggi daripada produk non organic. Keterlibatan pemerintah perlu diintesifkan, kebijakan harga dasar bagi produk pertanian bisa dipertahankan tetapi ceiling price (harga atas) harus dihilangkan untuk memberi kesempatan petani menikmati keuntungan dari harga yang tinggi. Mempermudah pemberian pinjaman dengan jaminan pemerintah dan bunga rendah; melindungi lahan persawahan dari degradasi lingkungan; mobilisasi potensi seluruh lembaga riset pertanian untuk mengembangkan teknologi pertanian yang sesuai dengan karakter geografis dan sosial budaya Indonesia. Pengembangan tersebut meliputi masalah pembibitan, mekanisasi proses tanam dan panen, pengairan, listrik; mendorong terbangunya pertanian kolektif dengan pengolahan lahan bersama serta penerapan teknologi yang lebih maju yang melibatkan petani dalam mengambil 
keputusan; mengembangkan industri pengolahan hasil pertanian sesuai dengan komoditi pertanian (Oktavianus, 2008).

Petani kita selama ini sering merana akibat masuknya produk pertanian dari luar baik yang legal maupun ilegal. Negara perlu untuk memproteksi petani dengan jalan mengehentikan produk pertanian impor atau dengan mengenakan pajak yang besar pada produk pertanian impor. Kebijakan ini perlu dilakukan bukan karena kualitas produksi pertanian kita kalah, tetapi oleh harga produk impor yang relatif lebih murah dari produk lokal. Mendayagunakan produkproduk pertanian, tidak hanya produk mentahnya saja tetapi mencoba menjual produk-produk pertanian olahan, perbaikan kemasan hingga system distribusi dan penjualan yang disempurnakan.

\section{F. Kesimpulan}

Industrialisasi adalah sebuah proses jangka panjang. Proses tersebut tidak bisa dilakukan secara melompat. Suatu kesalahan besar dalam industrialisasi adalah ketika pemerintahan over optimistime, yang melompat jauh membangun industri yang esbenarnya tidak dapat mendukung industri tersebut secara ekonomi dan sosial, seperti pendidikan, keterampilan, nilai-nilai yang berkembang. Kalau pembangunan industri semacam ini dipaksakan, maka industri ini harus terus menerus dilindungi dan tidak bisa menjadi kuat.

Keberhasilan banyak negara dalam melakukan industrialisasi justru ditopang oleh sektor pertanian yang digunakan sebagai pijakan untuk masuk ketahap industrialisasi yang sesungguhnya. Pengembangan sektor pertanian akan menyeret perkembangan sektor sosial dan budaya yang menjadi landasan dasar suksesnya industrialisasi. Salah satu syarat untuk mengejar ketertinggalan dari negara maju adalah kemampuan sosial yang cukup, dimana masyarakatnya harus cukup maju untuk menyesuaikan teknologi dari negara-negara maju. Investasi SDM juga merupakan salah satu bagian penting terutama ketika dikaitkan antara pendidikan dengan industri. Membangun industrialisasi kembali (re-industrialisation) mutlak memerlukan campur tangan yang besar dari negara. Peran negara disini tidak sama dengan menyerahkan ekonomi pada mekanisme pasar, pasar justru akan menjadi jebakan bagi industrialisasi jika tidak ada pengaturan. Intervensi negara diperlukan untuk mengoreksi kegagalan pasar, diantaranya negara harus menjamin tersedianya sumber energi yang memadai untuk seluruh jenis industri; kebijakan strategi industri harus menghasilkan pembangunan industri pengolahan bahan baku menjadi bahan setengah jadi; menjamin tersedianya pasar bagi industri yang masih membutuhkan proteksi dengan pengenaan pajak atau cukai yang tinggi terhadap komoditi sejenis yang diimpor dari luar negeri; dan menyediakan sumber daya manusia yang berkualitas. 
| Keterpurukan Sektor Pertanian

Daftar Pustaka

Budiman, Arief, 2000., Teori Pembangunan Dunia Ketiga, Jakarta: Gramedia

Daeng, Salamuddin, 2009., Industrialisasi: "Apa dan Bagaimana Indonesia" [online] tersedia pada URL:

$<$ http://www.globaljust.org/index. php?option $=$ com_content\&task $=$ vie $\mathrm{w} \& \mathrm{id}=178 \&$ Itemid $=131 \&$ lang $=\mathrm{id}>$

[diakses pada 26 Januari 2009]

Effendi, Tadjuddin, 1995., Sumber Daya Manusia Peluang Kerja dan Kemiskinan, Yogyakarta: Tiara Wacana

Irham, 2006., Mungkinkah terjadi Revolusi Hijau Babak II [online] tersedia pada URL: <http://nasih.staff.ugm.ac.id/a/pe rt/2006915 mu.htm> [diakses pada 28 Januari 2009]

Laeyendecker, 1983., Tata Perubahan dan Ketimpangan: Suatu Pengantar Sejarah Sosiologi, Jakarta: Gramedia

Noertjahyo, 2005., Dari Ladang sampai Kabinet, Menggugat Nasib Petani, Jakarta: Kompas
Oktavianus, Dominggus, 2008., Industrialisasi Nasional dan Cita-cita Kemakmuran [online] tersedia pada URL:

<http://pijarapi.multiply.com/jour nal/item/24> [diakses pada 26 Januari 2009]

Prabowo, Hermas, 2008., Menuju Negara Pertanian Termaju di Dunia [online] tersedia pada URL: <http://www.kompas.com/read/x $\mathrm{ml} / 2008 / 12 / 09 / 08535413 /$ menuju. negara.pertanian.termaju.di.dunia $>$ [diakses pada 26 Januari 2009]

Sanderson, Stephen, 2003., Makro Sosiologi, Jakarta: Rajawali Press

Suhendra, Susi, Analisis Struktur Sektor Pertanian Indonesia: Analisis Mode Input-Output, Jurnal Ekonomi $\mathcal{E}$ Bisnis, Vol. 9, No.2, 2004, pp. 5565

Weber, Max, 2006., Etika Protestan dan Spirit Kapitalisme, Yogyakarta: Pustaka Pelajar

Weiss, John, 2002., Industrialisation and Globalisation: Theory and Evidence from Developing Countries, London: Routledge 